\title{
Trace amounts of saxitoxins in the viscera of chum salmon Oncorhynchus keta
}

\author{
Shigeru Sato, Takehiko Ogata, Masaaki Kodama* \\ School of Fisheries Sciences, Kitasato University, Sanriku, Iwate 022-0101, Japan
}

\begin{abstract}
Low levels of saxitoxins and tetrodotoxin were found in the viscera of adult chum salmon Oncorhynchus keta returning to spawn. The nucleic magnetic resonance and mass spectrum analyses as well as several kinds of chromatographies clearly showed that the purified toxins were saxitoxin and neosaxitoxin. Tetrodotoxin, which was detected by high performance liquid chromatography analysis, could not be isolated. These findings show that saxitoxins and tetrodotoxin are more widely distributed in aquatic organisms than previously thought.
\end{abstract}

KEY WORDS: Saxitoxin - Tetrodotoxin - Chum salmon - Oncorhynchus keta

In a previous paper (Sato et al. 1993), we observed sodium channel blocking activity in extracts of various common aquatic species, though the activity was very low. When the toxin with this activity was partially purified and analyzed by high performance liquid chromatography (HPLC) (Yotsu et al. 1989, Oshima 1995), saxitoxins (STXs) and tetrodotoxin (TTX) were detected (Sato et al. 1993). STXs are well-known dinoflagellate toxins which cause paralytic shellfish poisoning (Schantz 1986). STXs occur in various aquatic organisms other than dinoflagellates, including xanthid crabs (Noguchi et al. 1969), horseshoe crabs (Fusetani et al. 1982), marine snails (Kotaki et al. 1981) and puffers (Kodama et al. 1983, Sato et al. 1997). On the other hand, TTX is a neurotoxin which binds to the same receptor as STXs (Kao 1966). TTX is a wellknown puffer toxin, but is known to occur in other aquatic species (Mosher \& Fuhrman 1984). Species which possess either STXs or TTX are now known to possess both toxins, that is, TTX has been detected in xanthid crabs (Noguchi et al. 1983) and horseshoe

-Addressee for correspondence.

E-mail: m-kodama@nnet.ne.jp crabs (Kungsuwan et al. 1987, Saitanu et al. 1988), while STXs have been found in puffers (Kodama et al. 1983, Sato et al. 1997). Recently, TTX was detected in Alexandrium tamarense, a representative dinoflagellate which produces STXs (Kodama et al. 1996). These findings suggest that TTX and STXs are widely distributed in natural ecosystems in certain species. By contrast, our previous results show that TTX and STXs are not specific toxins detected in selected species, but are distributed widely among common aquatic species at low levels. If true, this becomes important from the standpoint of the origin and the biological impact of these toxins. In the present study, we chose chum salmon Oncorhynchus keta because TTX, STX and neosaxitoxin (neoSTX) have been detected in this species by HPLC analysis (Sato et al. 1993); we purified sodium channel blocking toxins from the viscera to a highly purified state. We report here the occurrence of STX and neoSTX in the viscera of chum salmon with additional and more convincing chemical evidence.

Viscera were collected from chum salmon Oncorhynchus keta caught at the river mouth of Sakari river, Iwate, Japan, during November and December, the homing period of the salmon, in 1995. A total of $62 \mathrm{~kg}$ of viscera was collected. Once near the mouth of the stream, more than $90 \%$ of the chum salmon which return to the parent river do not feed (Ueno 1993), and all stomachs in the viscera collected were empty.

The toxin in the viscera was extracted with 2 volumes of boiling $0.1 \mathrm{M}$ acetic acid and purified. During the purification process, the toxin was monitored by mouse bioassay and the toxin amount was expressed in mouse units (MU), where $1 \mathrm{MU}$ will kill a $20 \mathrm{~g}$ male mouse in $15 \mathrm{~min}$. About $6000 \mathrm{MU}$ of toxin was obtained. After an activated charcoal treatment (Kotaki et al. 1981), the crude toxin was applied to a column of Amberlite CG50 with mesh size of 100 to $200\left(\mathrm{Na}^{+}\right.$ form, $5 \times 70 \mathrm{~cm})$. The column was washed with a suffi- 
cient volume of water, and the substances adsorbed to Amberlite CG50 were eluted with $4000 \mathrm{ml}$ of $1 \mathrm{M}$. sodium acetate and $1 \mathrm{M}$ acetic acid, successively. In total T, $2590 \mathrm{MU}$ of the toxin was recovered in the $1 \mathrm{M}$ acetic acid fraction. A part of the toxin with more negative charge was eluted in the $1 \mathrm{M}$ sodium acetate fraction. However, we were unable to extract toxins from this fraction because of difficulties associated with purification of a small amount of toxins in a high concentration of sodium acetate solution. The toxin in the acetic acid fraction was further purified by repeated chromatography on Bio-Gel P-2 column (200 to 400 mesh, $5 \times 70 \mathrm{~cm}$ ) equilibrated with $0.03 \mathrm{M}$ acetic acid. The $2450 \mathrm{MU}$ of toxin recovered was then subjected to Bio-Rex 70 column chromatography $\left(\mathrm{H}^{+}\right.$form, -400 mesh, $1 \times 90 \mathrm{~cm}$ ) using linear gradient elution from $100 \mathrm{ml}$ of distilled water to $100 \mathrm{ml}$ of $1 \mathrm{M}$ acetic acid. Two toxic fractions (toxins 1 and 2) were obtained. Respective toxic fractions were further purified by HPLC on a Hitachi-gel $3011 \mathrm{C}$ column $(4.6 \times$ $250 \mathrm{~mm}$ ). In total, $1240 \mathrm{MU}$ of toxin 1 and $1010 \mathrm{MU}$ of toxin 2 were obtained in a highly purified state. In the HPLC-fluorometric analysis for STXs (Oshima 1995), by thin layer chromatography (Buckley et al. 1976) and by electrophoresis (Fallon \& Shimizu 1977), toxins 1 and 2 were indistinguishable from standards of STX and neoSTX (data not shown). The nucleic magnetic resonance spectra of toxins 1 and 2 measured in $\mathrm{D}_{2} \mathrm{O}$ coincide with those of standard STX and neoSTX measured under the same conditions (Table 1). Positive fast atom bombardment mass spectra of toxins 1 and 2 measured in a glycerol matrix showed ion peaks at $\mathrm{m} / \mathrm{z}=300$ and 316 which correspond to respective pseudomolecular ion peaks of STX and neoSTX. These data clearly show that STX and neoSTX are present in the viscera of chum salmon, and support our previous finding that STXs are not restricted to the selected species, but occur in a variety of aquatic organisms at low levels. We could not isolate TTX which we detected in the viscera of chum salmon by HPLC analysis (Sato et

Table 1. Comparison of nucleic magnetic resonance spectra ( ${ }^{\prime} \mathrm{H}-\mathrm{NMR}$ ) of toxin 1 and toxin 2 isolated from the viscera of chum salmon Oncorhynchus keta with those of standard saxitoxin and neosaxitoxin. s: singlet; d: doublet; dd: double doublet, m: multiplet. Neosaxitoxin data from Shimizu et al. (1978)

\begin{tabular}{|c|c|c|c|c|}
\hline \multirow{2}{*}{$\begin{array}{l}\text { Carbon } \\
\text { no. }\end{array}$} & \multicolumn{4}{|c|}{ Chemical shift (coupling constant) } \\
\hline & Toxin 1 & Toxin 2 & Saxitoxin & Neosaxitoxin \\
\hline H5 & 4.685 & $4.78 \mathrm{~s}$ & $4.66 \mathrm{~s}$ & $4.74 \mathrm{~s}$ \\
\hline H6 & $3.78 \mathrm{~m}$ & $406 \mathrm{dd}(6,6.5)$ & $3.77 \mathrm{~m}$ & $3.96 \mathrm{dd}(6,6.5)$ \\
\hline \multirow{2}{*}{$\mathrm{H} 10$} & $3.75 \mathrm{~m}$ & $3.76 \mathrm{dd}(11.10)$ & $3.73 \mathrm{~m}$ & $3.67 \mathrm{~d}(10)$ \\
\hline & $3.55 \mathrm{~m}$ & $3.54 \mathrm{~m}$ & $3.52 \mathrm{~m}$ & $3.46 \mathrm{~d}(1.0)$ \\
\hline H11 & $2.33 \mathrm{~m}$ & $2.35 \mathrm{~m}$ & $2.30 \mathrm{~m}$ & $2.13 \mathrm{~m}$ \\
\hline \multirow[t]{2}{*}{$\mathrm{H} 13$} & $4.28 \mathrm{dd}(11,9)$ & $4.38 \mathrm{dd}(12,6)$ & $4.22 \mathrm{dd}(11,9)$ & $4.41 \mathrm{dd}(12,6)$ \\
\hline & $3.98 \mathrm{dd}(11.6)$ & $4.18 \mathrm{dd}(12,6)$ & $3.94 \mathrm{dd}(11,9)$ & $4.22 \mathrm{dd}(12,6.5)$ \\
\hline
\end{tabular}

al. 1993). During the purification process, about half the toxin was lost in the Amberlite CG50 chromatography. Probably TTX was lost in the $1 \mathrm{M}$ sodium acetate fraction in the chromatography because of its weaker positive charge than STX and neoSTX.

STXs are produced by several species of dinoflagellates (Schantz 1986). During a bloom of these dinoflagellates, bivalves become toxic by accumulating STXs from dinoflagellates via the food chain (Schantz 1986). However, the origin of STXs in species other than those which are associated with dinoflagellates is unknown. A low level of STXs is produced by bacteria isolated from toxic dinoflagellates such as Alexandrium tamarense (Kodama et al. 1988, Doucette \& Trick 1995, Gallacher et al. 1997). Bacteria known to produce STXs may be widely distributed in marine ecosystems (Kodama et al. 1990, Sakamoto et al. 1992, Levasseur et al. 1996). In a previous paper (Sato et al. 1993), no significant difference in toxin potency was observed from viscera of various common species representing diverse phyla, indicating that the toxin was not accumulated at higher levels in the food web. The observation that all stomachs in the viscera used in the present study were empty supports our contention that toxins do not originate from diet, although regurgitation may have occurred. These facts suggest that a low level of STXs in viscera from common aquatic species may be due to STXs-producing bacteria from the intestinal bacterial flora occurring naturally.

On the other hand, TTX is a well-known toxin produced by bacteria (Noguchi et al. 1986, Yasumoto et al. 1986). TTX-producing bacteria are reported to occur widely in marine ecosystems (Simidu et al. 1987). For example, Noguchi et al. (1987) report that TTX is produced by Vibrio alginolyticus, which is known to be distributed widely in the oceans and in the intestinal bacterial flora of marine species. These facts suggest that most marine organisms are exposed to TTX-producing bacteria. Although we lost the TTX-like toxin during the purification procedures in the present study, it is possible that a low level of TTX from environmental bacteria may occur in common aquatic species together with STXs. It has been suggested that the selected organisms which possess high amounts of TTX and STXs accumulate these toxins via the food web (Yasumoto \& Yotsu 1992). Species which possess both STXs and TTX are highly resistant to these toxins (Saito et al. 1985, Daigo et al. 1988), and this resistance may be associated with their ability to accumulate a high level of these toxins. Our results indicate that these toxins 
occur in common aquatic species at low levels. Apparently, these may support a dietary mechanism by which the selected organisms such as puffer accumulate high amounts of toxins. However, puffer show a remarkable individual difference in toxicity (Kodama et al 1984), though no significant difference was observed in toxin potency from viscera of various common species which could be in the diet of puffer (Sato et al. 1993). Therefore, puffer seem to accumulate high amounts of toxins by an unknown mechanism other than food-web interaction. Previously, we reported that toxic specimens of puffer are infected by bacteria which produce a TTX-like substance, while no such infection was observed in nontoxic specimens (Kodama et al. 1995). Accumulation of high amounts of TTX and STXs in the selected organisms seems to be due to the infection of these toxin-producing bacteria.

Acknowledgements. This study was supported in part by a grant-in-aid from the Ministry of Education, Science and Culture of Japan, and a grant from the Waxman Foundation of Japan Inc. We are grateful to Dr M. Murakami, Associate Professor at Tokyo University, for his help in obtaining mass spectra and nucleic magnetic resonance spectra.

\section{LITERATURE CITED}

Buckley LJ, Ikawa M. Sasner JJ Jr (1976) Isolation of Conyaulax tamarensis toxins from soft shell clams (Mya arenaria) and a thin-layer chromatographic-fluorometric method for their detection. J Agric Food Chem 24:107-111

Daigo K, Noguchi T, Miwa A, Kawai N, Hashimoto K (1988) Resistance of nerves from certain toxic crabs to paralytic shellfish poison and tetrodotoxin. Toxicon 26:485-490

Doucette GJ, Trick CG (1995) Characterization of bacteria associated with different isolates of Alexandrium tamarense. In: Lassus P, Arzul G, Denn EEL, Gentien P, Baut CML (eds) Harmful marine algal blooms. Lavoisier, Paris, p $33-38$

Fallon WE, Shimizu Y (1977) Electrophoresis analysis of paralytic shellfish toxins. J Environ Sci Health A12:455-464

Fusetani N, Endo H, Hashimoto K, Takahashi K (1982) Occurrence of potent toxins in the horseshoe crab Carcinoscorpius rotundicauda. Toxicon 20:662-664

Gallacher S, Flynn KJ, Franco JM, Brueggemann EE, Hines $\mathrm{HB}$ (1.997) Evidence for production of paralytic shellfish toxins by bacteria associated with Alexandrium spp. (Dinophyta) in culture. Appl Environ Microbiol 63: $239-245$

Kao CY (1966) Tetrodotoxin, saxitoxin and their significance in the study of excitation phenomena. Pharmacol Rev 18: $997-1049$

Kodama M, Ogata T, Noguchi T, Maruyama J, Hashimoto K (1983) Occurrence of saxitoxin and other toxins in the liver of the pufferfish Takifugu pardalis. Toxicon 21:897-900

Kodama M, Ogata T, Kawamukai K, Oshima Y, Yasumoto T (1984) Toxicity of muscle and other organs of five species of puffer collected from the Pacific coast of Tohoku area of Japan. Bull Jpn Soc Sci Fish 50:703-706

Kodama M, Ogata T, Sato S (1988) Bacterial production of saxitoxin. Agric Biol Chem 52:1075-1077

Kodama M, Ogata T, Sato S, Sakamoto S (1990) Possible asso- ciation of marine bacteria with paralytic shellfish toxicity of bivalves. Mar Ecol Prog Ser 61:203-206

Kodama M, Shimizu H, Sato S, Ogata T, Terao K (1995) The infection of bacteria in the liver cells of toxic puffer-a possible cause for organisms to be made toxic by tetrodotoxin in association with bacteria. In: Lassus P, Arzul G, Denn EEL, Gentien P. Baut CML (eds) Harmful. marine algal blooms. Lavoisier, Paris, p 457-462

Kodama M, Sato S, Sakamoto S, Ogata T (1996) Occurrence of tetrodotoxin in Alexandrium tamarense, a causative dinoflagellate of paralytic shellfish poisoning. Toxicon 34 : $1101-1105$

Kotaki Y, Oshima Y, Yasumoto T (1981) Analysis of paralytic shellfish toxins of marine snails. Bull Jpn Soc Sci Fish 47 : 943- 946

Kungsuwan A, Nagashima Y, Noguchi T, Shida Y, Suvapeepan S, Suwansakornkul P, Hashimoto K (1987) Tetrodotoxin in the horseshoe crab Carcinoscorpius rotundicauda inhabiting Thailand. Nippon Suisan Gakkaishi 53: 261-266

Levasseur M, Monfort P, Doucette GJ, Michaud S (1996) Preliminary study of bacteria as PSP producers in the Gulf of St. Lawrence, Canada. In: Yasumoto T, Oshima Y, Fukuyo $Y$ (eds) Harmful and toxic algal blooms. Intergovernmental Oceanographic Commission of UNESCO Paris. p 363-366

Mosher HS, Fuhrman FA (1984) Occurrence and origin of tetrodotoxin. In: Ragelis EP (ed) Seafood toxins. American Chemical Society, Washington, DC, p 333-344

Noguchi T, Konosu S, Hashimoto Y (1969) Identity of the crab toxin with saxitoxin. Toxicon 7:325-326

Noguchi T, Uzu A, Koyama K. Maruyama J, Nagashima Y, Hashimoto $K$ (1983) Occurrence of tetrodotoxin as the major toxin in a xanthid crab Atergatis floridus. Bull Jpn Soc Sci Fish 49:1887-1892

Noguchi T, Jeon J, Arakawa O, Sugita $H$, Deguchi $Y$, Shida $Y$, Hashimoto K (1986) Occurrence of tetrodotoxin and anhydrotetrodotoxin in Vibrio sp isolated from the intestines of a xanthid crab, Atergatis floridus. J Biochem 99: $311-314$

Noguchi T, Hwang DF, Arakawa O, Sugita H, Deguchi Y, Shida Y, Hashimoto K (1987) Vibrio alginolyticus, a tetrodotoxin-producing bacterium, in the intestines of the fish Fugu vermicularis vermicularis. Mar Biol 94:625-630

Oshima Y (1995) Postcolumn derivatization liquid chromatography method for paralytic shellfish toxins. J Assoc Off Anal Chem Int 78:528-532

Saitanu K, Piyakarnchana $T$, Sato $S$, Ogata $T$, Kodama M (1988) Toxicity of two species of horseshoe crab in Thailand. In: Gopalakrishnakone P, Tan CK (eds) Progress in venom and toxin research (Proceedings of the first AsiaPacific Congress on Animal, Plant and Microbial Toxins, Singapore, 24-27 June 1987). National University of Singapore, Singapore, p 493-4.98

Saito T, Noguchi T, Harada T, Murata $O$. Abe T. Hashimoto $\mathrm{K}$ (1985) Resistibility of toxic and non-toxic pufferfish against tetrodotoxin. Bull Jpn Soc Sci Fish 48:1371

Sakamoto S, Ogata T, Sato S, Kodama M, Takeuchi T (1992) Causative organism of paralytic shellfish toxins other than toxic dinoflagellates. Mar Ecol Prog Ser 89:229-235

Sato S, Ogata T, Kodama M (1993) Wide distribution of toxins with sodium channel blocking activity similar to tetrodotoxin and paralytic shellfish toxins in marine animals. In: Smayda TJ, Shimizu Y (eds) Toxic phytoplankton blooms in the sea. Elsevier, New York, p 429-434

Sato S. Kodama M, Ogata T, Saitanu K, Furuya M, Hirayama K. Kakinuma K (1997) Saxitoxin as a toxic principle of a 
freshwater puffer, Tetraodon fangi, in Thailand. Toxicon 35: $137-140$

Schantz EJ (1986) Chemistry and biology of saxitoxin and related toxins. Ann NY Acad Sci 479:15-23

Shimizu Y, Hsu CP, Fallon WE, Oshima Y, Miura I, Nakanishi K (1978) Structure of neosaxitoxin. J Am Chem Soc 100: $6791-6793$

Simidu U, Noguchi T, Hwang DF, Shida Y, Hashimoto K (1987) Marine bacteria which produce tetrodotoxin. Appl Environ Microbiol 53:1714-1715

Ueno Y (1993) Studies on the ecology and resource of matur-

Editorial responsibility: Otto Kinne (Editor),

Oldendorf/Luhe, Germany ing chum salmon off the Pacific coast of northern Honshu. Bull Natl Inst Far Seas Fish 30:80-206 (in Japanese)

Yasumoto $T_{\text {, Yotsu }} \mathrm{M}$ (1992) Biogenetic origin and natural analogs of tetrodotoxin. In: Keeler RF, Mandava NB, Tu AT (eds) Natural toxins: toxicology, chemistry and safety. Alaken, Fort Collins, p 226-233

Yasumoto $T$, Yasumura D, Yotsu $M$, Michishita T, Endo A, Kotaki Y (1986) Bacterial production of tetrodotoxin and anhydrotetrodotoxin. Agric Biol Chem 50:793-795

Yotsu M, Endo A, Yasumoto T (1989) An improved tetrodotoxin analyzer. Agric Biol Chem 53:893-895

Submitted: June 30, 1998; Accepted: November 3, 1998

Proofs received from author(s): December 8, 1998 